\title{
PENETRASI NEGARA TERHADAP KELEMBAGAAN ADAT NAGARI PARIANGAN DI ERA OTONOMI DAERAH
}

\author{
Yayan Hidayat ${ }^{1}$ dan Anang Fajar Sidik ${ }^{2}$ \\ ${ }^{1}$ Aliansi Masyarakat Adat Nusantara (AMAN) \\ Tebet Timur Dalam No. 11A, Jakarta Selatan, DKI Jakarta \\ ${ }^{2}$ CIJFD Community, Brawijaya University, Malang \\ E-mail: yayanhidayat20@gmail.com
}

\begin{abstract}
ABSTRAK
Tulisan ini menjelaskan tentang pola dan dinamika hubungan negara terhadap lembaga adat Nagari Pariangan dalam otonomi daerah. Tujuan dari penelitian ini adalah untuk mengetahui bagaimana negara memainkan pola penetrasi melalui institusi formal, hukum, kebijakan publik, dan proses politik dalam hubungan negara dengan Nagari. Kami menemukan kondisi tersebut karena, pertama, kepentingan negara untuk secara intensif mengendalikan sumber daya alam dan ekonomi di Nagari. Kedua, kepentingan pemerintah daerah untuk menciptakan stablisasi politik sebagai kebutuhan inti pembangunan ekonomi di era otonomi. Penetrasi dan transformasi Nagari berdampak pada penyederhanaan Nagari menjadi birokrasi modern sehingga sesuai dengan kepentingan negara. Pendekatan historical institusionalisme digunakan sebagai alat analisis untuk mengurai pola penetrasi negara yang terjadi pada Nagari. Otonomi daerah tidak membuat Nagari mandiri sebagai pemerintahan sendiri, mereka masih menghadapi intervensi dari pemerintah pusat. Itulah salah satu alasan kuat mengapa penelitian ini dilakukan. Hasil penelitian ini menunjukkan bagaimana pengakuan Nagari sebagai pemerintahan terendah sebenarnya dalam situasi yang dilematis, dimana Nagari harus menerima intervensi pemerintah pusat yang menempatkannya sebagai bagian dari birokrasi, bukan kemudian mengakui Nagari sebagai pemerintahan adat.
\end{abstract}

Kata Kunci : Nagari, Penetrasi Negara, Otonomi Daerah

\section{STATE PENETRATION ON INDIGENOUS INSTITUTION OF NAGARI PARIANGAN IN LOCAL AUTONOMY ERA}

\begin{abstract}
This paper explained the pattern and dynamic relation of the state towards indigenous institutional Nagari Pariangan in the local autonomy era. This research aims to reveal how the state is playing the penetration pattern through a formal institution, law, public policy, and political processes in state-relation towards Nagari. We found those condition caused by the state interest to intensively power control upon natural resources and economic in Nagari. In addition, local government interests to created political stabilization as a core requirement of economic development in autonomy era. Those, penetration and transformation impact to simplifying of Nagari into modern bureaucracy so that in line with state interest. Historical institutionalism approach used as a tool of analysis to elaborate the state penetration pattern that happened in Nagari. Autonomy era does not make Nagari independent as self-government, they still facing intervention from central government. The result of this research shows how the recognition of Nagari as a low government put on the dilemmatic situation, in which Nagari had to accept central government intervention placed it as a part of the bureaucratic state.
\end{abstract}

Keywords: Nagari, state-penetration, local autonomy

\section{PENDAHULUAN}

Rezim pemerintahan Orde Baru yang sentralistik telah mengubah sistem dan bentuk pemerintahan lokal level paling bawah di Nagari. Penetrasi negara masa itu diperkuat melalui UU No. 5/1979 yang mengubah pemerintahan Nagari menjadi pemerintahan desa. Perubahan
Nagari ke bentuk desa bukan hanya sekedar perubahan nama, melainkan merubah sistem, orientasi dan filosofi Nagari (von BendaBeckmann, 1979). Akibatnya, banyak kelembagaan adat Nagari yang dihapuskan dan diganti dengan kelembagaan negara untuk memperkuat dominasi rezim. Nagari sebagai kesatuan masyarakat adat terpecah menjadi 
beberapa desa, terdapat 543 desa pada saat pembentukannya di Sumatera Barat, jauh lebih besar dari jumlah Nagari yang awalnya sebanyak 300-an kenagarian (Yasril, 2007). Secara kultural, perubahan dari pemerintahan Nagari ke pemerintahan desa di Sumatera Barat menimbulkan beberapa implikasi. Pertama, kepemimpinan formal terendah telah bergeser dari kepemimpinan kolektif tali tigo sapilin dan tungku tigo sajarangan kepada kepala desa yang sebenarnya tidak cukup legitimed dihadapan warga. Kedua, perubahan tersebut telah merusak adat dan menghilangkan identitas anak Nagari dan melunturkan ikatan genealogi.

Runtuhnya rezim Orde Baru dan dikeluarkannya Undang-Undang Nomor 22 Tahun 1999 yang mengatur desentralisasi dan memberikan hak otonomi kepada daerah memang menjadi kesempatan pertama bagi daerah-daerah di Indonesia untuk menegaskan lokalitas bentuk pemerintahannya. Namun, hal tersebut justru meninggalkan persoalanpersoalan baru seperti kecenderungan bergantung pada pusat pemerintahan yang tersisa sejak sebelum reformasi. Sebagaimana di daerah lainnya, hal ini direspons oleh pemerintah Provinsi Sumatera Barat yang mengembalikan bentuk pemerintahan lokal kembali ke bentuk Nagari dengan mengeluarkan Perda Nomor 9 Tahun 2000. Transformasi tersebut menyebabkan terjadinya perubahan baik dalam struktur pemerintahan dan peraturan yang berlaku dalam tatanan masyarakat Nagari.

Pada saat desa dihapuskan dan Nagari dihidupkan kembali, semestinya penerapan lembaga pemerintahan juga ikut berubah. Namun, dalam kenyataannya tidak demikian kelembagaan yang ada dalam struktur desa tidak dihapuskan, ketika institusi tradisional dihidupkankembaliNagarimengalamidualisme kelembagaan (L.M, 2009). Dalam kasus pemerintahan Nagari, kebijakan dan intervensi pemerintah terhadap pemerintahan Nagari merupakan salah satu faktor yang menyebabkan timbulnya perubahan sosial melalui caracara yang struktural dalam masyarakat (Jong, 1980). Dampak yang dirasakan justru kepada masyarakat, terutama ikatan sosial yang terjalin diantara masyarakat menjadi lemah, bahkan masyarakat sedikit sekali memiliki kesadaran untuk berpartisipasi dalam proses politik dan pemerintahan berdasarkan kesadaran. Padahal melaksanakan sistem pemerintahan Nagari juga mencakup keterlibatan secara sadar anak kemenakan dan urang kampuang yang terlibat dalam penyelenggaraan Nagari.

Dalam tulisan ini, penetrasi negara diartikan sebagai kebijakan atau tindakan yang diambil oleh negara dalam rangka merumuskan dan menegakkan aturan permainan dalam kehidupan ekonomi (Patji, 2004), politik, dan kemasyarakatan baik secara horizontal maupun vertikal atau teritorial. Penelitian sebelumnya yang mengulas hal serupa dilakukan oleh Raja Sofyan (Samad, 2010) tentang studi penetrasi negara di Kepulauan Riau di masa Orde Baru. Bedanya dengan tulisan ini adalah pembahasan penelitian Raja Sofyan masih mengulas mengenai Orde Baru yang otoriter. Sedangkan tulisan ini mengulas penetrasi di era otonomi daerah yang lebih terbuka. Pengertian penetrasi negara dalam studi ini sengaja dipersempit, sebab negara sebagai institusi politik sesungguhnya memainkan dua fungsi penting. Pertama mengatur, bukan mengontrol kehidupan ekonomi dan kedua monopoli penggunaan kekerasan fisik sebagai instrumen sosial kontrol. Negara menentukan pola dominasi di dalam masyarakat melalui lembaga-lembaga Negara pada bidangnya masing-masing. Negara mengatur kewenangan lembaga dan mengikat keputusan masyarakat serta lembaga, khususnya kelembagaan adat melalui hukum-hukum negara modern pada umumnya menembus komunitas-komunitas masyarakat sipil dan mengimplementasikan logika politik dalam seluruh keputusan pada bidang-bidang negara.

Studi ini mengambil objek penelitian di Nagari Pariangan Kabupaten Tanah Datar. Selama rentang tiga bulan, mulai Oktober hingga Desember 2017 penulis melakukan penelitian di wilayah tersebut. Sebagai Nagari tertua menurut tambo sejarah alam Minangkabau. Nagari Pariangan sebagai Nagari tertua saat ini menghadapi kondisi dilematis, pengakuan kembali Nagari sebagai pemerintahan terendah ternyata tidak berdampak apa-apa terhadap kelembagaan adat di Nagari Pariangan. Setelah mengalami perubahan, Nagari Pariangan harus mencari bentuknya kembali sebagai institusi politik yang kuat dalam memastikan aturan dan menyelesaikan persoalan-persoalan lokal yang berkaitan dengan kesejahteraan umum masyarakat adat. Tulisan ini berrfokus mengungkap bagaimana negara memainkan 
pola penetrasinya melalui kelembagaan formal, undang-undang, kebijakan, dan proses politik dalam relasi negara terhadap Nagari Pariangan di era otonomi daerah.

Tulisan ini menemukan bahwa kebijakan otonomi daerah tidak memberikan pengaruh yang signifikan terhadap kewenangan lembaga adat di Nagari dalam menentukan dan menjalankan bentuk pemerintahan sendiri sesuai dengan landasan tali tigo sapilin, tungku tigo sajarangan sebagai filosofi pemerintahan adat Nagari. Selalu ada intervensi pemerintah pusat dan daerah dalam tata kelola kelembagaan adat, intervensi tersebut muncul dari birokrasibirokrasi daerah, hukum formal dan proses politik yang cenderung membatasi kewenangan pemimpin adat di dalam Nagari. Interaksi yang terbangun dalam dualisme pemerintahan yang terjadi antara Wali Nagari sebagai pemerintahan dinas dan KAN (Kerapatan Adat Nagari) adalah interaksi penetratif yang melemahkan fungsi kelembagaan adat. KAN hanya dianggap sebagai pelaksana adat yang tidak memiliki kewenangan untuk mengambil keputusan atau terlibat dalam pembangunan Nagari. Hipotesis tersebut kemudian yang membedakan tulisan kami dengan penelitian tentang nagari pada umumnya yang hanya terfokus membahas pemerintahan Nagari dari aspek tata kelola birokrasi kelembagaan adat di era otonomi daerah.

\section{METODE}

Dalam melihat penetrasi negara di Nagari, tulisan ini menggunakan pendekatan Historical Institusionalism guna menganalisis transformasi kelembagaan, hubungan kekuasaan struktur dalam lembaga, aktor-aktor dalam kelembagaan serta berfokus pada proses politik dan pembuatan kebijakan dalam parameter kelembagaan. Historical institusionalism berusaha mengungkap perilaku dan tabi'at kelembagaan melalui analisis "jaringan kebijakan" yang menghubungkan antara Negara dan masyarakat. Ruang lingkup analisis bukan hanya konteks tapi juga tindakan (conduct) yang dilakukan sehingga ketika individu tersebut adalah aktor pembuat keputusan pada tingkat elit negara maka analisis bergeser ke level negara. Konsekuensinya, struktur negara menjadi alat yang dapat digunakan oleh individu untuk mempengaruhi perilaku masyarakat melalui penggunaan institusi (rules and regulations).
Atas dasar landasan teoritis tersebut, path dependence (jalur ketergantungan) sebagai alat analisis mencoba mengidentifikasi status quo dalam setiap perubahan yang terjadi. Selain itu, path dependence berusaha mengidentifikasi bounded rationality atau rasionalitas yang dibatasi dalam perubahan dari waktu ke waktu. Gagasan ini menganggap bahwa individu membuat keputusan dan rasionalitas individu dibatasi oleh pengambilan keputusan maupun keterbatasan kognitif yang bertindak mencari solusi yang memuaskan daripada yang optimal. Sebagai entitas politik, Nagari bukanlah institusi tunggal yang berdiri sendiri. Transformasi yang merembet pada dualisme kelembagaan adat dan dinas merupakan dampak dari hadirnya kekuatan politik lainnya yang memberikan pengaruh terhadap perubahan Nagari selama masa reformasi. Analisis bounded rationality terhadap pola kekuatan politik yang memberikan pengaruh perubahan dalam Nagari menjadi titik kritis untuk menjawab pola dan kepentingan negara memainkan penetrasinya pada kelompok adat dalam Nagari. Pandangan ini bermaksud untuk menghindari keterbatasan analisis dan penglihatan terhadap faktor-faktor yang signifikan dalam transformasi Nagari.

Tulisan ini menggunakan pendekatan studi kasus untuk melihat Nagari sebagai realitas yang utuh, kompleks, dinamis dan penuh makna. Studi kasus dipilih karena penulis ingin melihat satu fenomena yang lebih mendalam. Kemudian Pengambilan data dilakukan dengan teknik wawancara secara langsung dan studi dokumentasi. Hal ini bertujuan supaya data yang diperolehsalingmelengkapi danmemperkuatsatu sama lain. Data yang diperoleh emudian diolah dengan berbagai tahapan seperti kondensasi yakni memilah dan menyederhanakan fenomena data yang semula abstrak, dan kemudian verifikasi untuk validitas data.

Untuk membedah kasus penetrasi negara dalam Nagari periode pasca reformasi, penulis menggunakan kasus tunggal dengan multi-analisis agar berfokus pada masalah dan kemudian menyeleksi satu kasus_serta dibatasi untuk membedah kasus yang sudah penulis tentukan yakni penetrasi Negara dalam Nagari. Dari kasus yang sudah penulis tentukan, menjadi dasar untuk mengidentifikasi narasumber yang mampu menjawab persoalan yang terjadi. Narasumber dalam penelitian ini adalah Ninik Mamak sebagai pemimpin adat di Nagari 
Pariangan, Wali Nagari sebagai pemimpin dinas sebagai representasi hadirnya Negara di Nagari, Wakil Ketua DPRD Kabupaten Tanah Datar sebagai pihak yang merumuskan regulasi relasi antara Nagari dan lembaga-lembaga negara, dan lembaga adat Cadiak Pandai sebagai cendikiawan di Nagari. Setelah data didapatkan maka akan dikelola melalui penjodohan dan pengumpulan pola serta mencari kesepadanan antara dua atau lebih kategori relasi negara dengan Nagari untuk menjawab bagaimana negara memainkan pola penetrasinya melalui kelembagaan formal, undang-undang, kebijakan, state actors dan proses politik melalui pendisiplinan yang dilakukan oleh negara terhadap Nagari Pariangan di era otonomi daerah.

Kebaruan dalam penelitian ini adalah membedah interaksi antara pola negara dan lembaga adat di era otonomi daerah. Interaksi tersebut kemudian dilihat sebagai bentuk yang penetratif terhadap adat. Kami mengidentifikasi interaksi negara dan lembaga adat Nagari tersebut menggunakan pisau analisis teori historical institusionalism yang menganalisis transformasi kelembagaan, hubungan kekuasaan struktur dalam lembaga, aktor-aktor dalam kelembagaan serta berfokus pada proses politik dan pembuatan kebijakan dalam parameter kelembagaan. Analisis Historical institusionalism dalam praktiknya berawal dari pemahaman yang menjelaskan bahwa pilihan terhadap sebuah kebijakan yang dibuat akan berpengaruh terhadap kebijakan selanjutnya dan pola tersebut akan berulang dan bertahan. Analisis ini kemudian yang banyak membantu tulisan ini membedah sebatas mana kebijakan otonomi daerah berpengaruh terhadap kewenangan lembaga adat di Nagari.

\section{HASIL DAN PEMBAHASAN}

Berdasarkan hasil penelitian terhadap perubahan-perubahan nagari pariangan serta relasi antara Negara dan nagari dalam kebijakan penyempurnaan nagari di era kebijakan otonomi daerah penulis menyimpulkan bahwa negara melalui Pemerintah Provinsi Sumatera Barat mendominasi danmelakukan tindakan penetratif dalam relasinya dengan nagari pada kebijakan penyempurnaan nagari pasca reformasi. Hal ini terlihat dari upaya Pemerintah Provinsi Sumatera Barat menciptakan perluasan birokrasi di dalam Nagari melalui regulasi formal, kebijakan yang dihasilkan, kelembagaan dan proses politik yang terjadi cenderung melemahkan kewenangan KAN sebagai lembaga adat karena dianggap menghambat agenda pembangunan dan tidak mampu menyelesaikan permasalahan pemerintahan.

Dominasi dalam ketentuan penyempurnaan nagari pada dasarnya merupakan keinginan pemerintah untuk menciptakan stabilitas politik sebagai persyaratan pembangunan ekonomi di era otonomi daerah. Proses transisi kelembagaan dan dilema distribusikewenangan terhadap lembaga adat dari setiap rangkaian regulasi dan kebijakan penyempurnaan Nagari merupakan pola model penetrasi yang berulang dan bertahan sejak masa orde baru di dalam Nagari. Meskipun pemerintah melalui peraturan-peraturan yang dihasilkan telah mengakui kewenangan kelembagaan adat tali tigo sapilin, tungku tigo sajarangan dalam nagari namun keputusan dan kewenangan tertinggi dalam adat tetap pada Pemerintah Kabupaten. Tumpang tindih peraturan Nagari, penyederhanaan kelembagaan adat Nagari, hadirnya dualisme kelembagaan antara KAN dan Wali Nagari memberikan jawaban bahwa gambaran tentang kebijakan kembali ber-nagari masih banyak kelemahan dalam membebaskan kewenangan lembaga adat untuk mengatur urusannya sendiri, karena lebih didominasi oleh keinginan pemerintah untuk melakukan reformulasi kelembagaan nagari agar selaras dengan sistem pemerintahan desa pada umumnya sebagai pola Orde Baru yang berulang di era reformasi dalam memandang nagari sebagai pemerintahan terendah bukan kesatuan genealogis masyarakat.

Nagari mengalami banyak perubahanperubahan secara struktur maupun kultur sejak hadirnya kolonialisme. Berbagai ketentuan struktur dan administratif diterapkan guna mengintensifkan kekuasaan dan mendorong terwujudnya agenda utama pemerintah yakni ketertiban, pengawasan dan pembangunan di Nagari. Nagari telah mengalami proses panjang pengaturan-pengaturan kelembagaan yang terjadi di setiap rezim. Dari mulai hidup kolektif dengan ikatan genealogis nagari, berstatus menjadi desa hingga kembali ke nagari. Banyak perubahan orientasi terjadi dalam struktural maupun kultural kelembagaan. Akibat banyaknya pengaturan yang terjadi di nagari, dalam pembahasan ini penulis hanya 
terfokus pada pengaturan nagari era reformasi yang memberikan banyak pengaruh terhadap kewenangan kelembagaan adat dalam Nagari.

\section{Kebijakan Baliak ka Nagari}

Pasca dikeluarkan Undang-Undang Desentralisasi nomor 22 Tahun 1999, Pemerintah Provinsi Sumatera Barat berupaya merumuskan ketentuan-ketentuan untuk kembali mengembalikan tata pemerintahan adat Nagari dalam masyarakat Minangkabau. Melalui Perda Nomor 9 tahun 2000 tentang pokok-pokok pemerintahan Nagari mengatur sedemikian rupa struktur adat tali tigo sapilin, tungku tigo sajarangan sebagai kepemimpinan kolektif beserta kewenangannya di era reformasi. Nagari yang berdiri atas kebijakan Perda Nomor 9 tahun 2000 merupakan Nagari yang mengalami penyederhanaan menyesuaikan kepentingan daerah. Konsep kebijakan kembali ke bernagari ini mencoba menyatukan kepemimpinan adat yang direpresentasikan oleh KAN dan pemimpin dinas yakni Wali Nagari berbentuk dualisme kepemimpinan dalam satu wadah Nagari sebagai struktur pemerintahan terendah Pemerintah Provinsi Sumatera Barat.

Perda Nomor 9 tahun 2000 tetap menghadirkan kelembagaan adat yang dibentuk saat Nagari berbentuk desa pada masa orde baru yakni Lembaga Kerapatan Adat Alam Minangkabau (LKAAM) sebagai lembaga supra-Nagari tingkat Provinsi. Lembaga ini menjadi perpanjangan tangan pemerintah untuk mengontrol aktivitas Ninik Mamak sebagai pemimpin suku di setiap Nagari. Beranggotakan para penghulu yang terhimpun dari masingmasing Nagari di Sumatera Barat. Seringkali lembaga ini mencampuri keputusan adat ketika bertentangan dengan kepentingan pemerintah. Selain itu, ada pula kelembagaan adat yang tidak diakui keberadaannya oleh Perda seperti lembaga unsur Parik Paga Nagari, Malin, Pandito dan Dubalang sebagai struktur di bawah Ninik Mamak karena dinilai tidak selaras dengan pemerintah dan dikhawatirkan akan memperkuat legitimasi Ninik Mamak sebagai pemimpin suku di setiap Nagari. Dengan berbagai perubahan yang ada dalam proses kembali bernagari, keputusan ini di nilai hanya sebatas prosedural dan masih dilematis. Dalam pengaturannya Perda Nomor 9 tahun 2000 memberikan kewenangan terhadap kelembagaan adat di Nagari namun sisi lain cenderung membatasi ruang kewenangan adat dengan kelembagaan-kelembagaan yang hadir sebagai perpanjangan tangan daerah di dalam Nagari.

Sebagaimana diungkapkan oleh lembaga unsur Cadiak Pandai Nagari Pariangan bahwa Perda nomor 9 tahun 2000 hanya dibuat berdasarkan beberapa Nagari yang ada tanpa berpedoman terhadap struktur Nagari yang sebenarnya sesuai ketentuan undang adat nan 20. Sisi lain, secara politik kebijakan kembali bernagari dipandang sebatas membangkitkan simbol kearifan lokal namun melupakan kewenangan lembaga adat yang sudah diatur dalampranataadatMinangkabau. Prosesregulasi Perda ini selain terlalu tergesa-gesa, DPRD Provinsi tidak melibatkan tokoh-tokoh adat dalam merumuskan ketentuan nagari sehingga Perda nomor 9 tahun 2000 tidak berlandaskan dengan ketentuan kelembagaan adat sesuai dengan tambo sejarah adat alam Minangkabau khususnya dalam syarat mendirikan Nagari. Akhirnya Nagari yang baru harus menyesuaikan bentuk-bentuk kelembagaan sesuai ketentuan di dalam Perda. Dampak yang dihasilkan oleh perda adalah terjadi tumpang tindih fungsi di dalam kelembagaan adat seperti KAN dan LKAAM, Bundo Kanduang dan PKK dan tumpang tindih landasan hukum antara Undang adat Nan 20, hukum Islam dan hukum formal.

\section{Monopoli Negara dalam Agenda Baliak ka Nagari}

Pemerintah daerah Sumatera Barat sendiri mencoba untuk mensinergikan unsur adat dan birokrasi modern dalam satu kelembagaan formal pemerintahan nagari. Alasan tersebut mendasari perubahan orientasi kelembagaan dalam kebijakan-kebijakan pendirian nagari seperti, posisi Wali Nagari yang sebelum kolonial berbentuk angku palo.

di geser dan diintegrasikan oleh daerah menjadi lembaga pelaksana daerah di dalam nagari serta bertanggung jawab terhadap bupati dalam menjalankan fungsi administratif, pembangunan dan pemberdayaan di dalam nagari. Fungsi kelembagaan KAN yang secara historis mengurusi adat-istiadat dan menjalankan roda pemerintahan di dalam nagari mulai dirubah dalam kebijakan baliak ka nagari.

Dampak dari keinginan integrasi kelembagaan tersebut, agenda baliak ka nagari 
menghasilkan dualisme kelembagaan di dalam tubuh nagari. Muncul Wali Nagari sebagai pemimpin formal yang mengurusi persoalan administratif dan pembangunan nagari serta KAN dalam tugasnya menghimpun seluruh Ninik Mamak di nagari dianggap pemimpin informal yang menyelesaikan sengketa sako dan pusako adat, mengarahkan dan membimbing kemenakan, menentukan sako dan pusako sesuai silsilah/ranji kaum serta bertanggung jawab terhadap keberlangsungan adat sesuai amanat undang adat nan 20. Persoalan nya sekarang KAN juga turut mengurusi tugas administratif nagari dan diharuskan untuk berkoordinasi dengan Wali Nagari dalam menjalankan roda pemerintahan nagari dalam menyelesaikan sengketa yang ada di nagari.

Di Nagari Pariangan kebijakan kembali ke pemerintahan nagari ditemukan berbagai persoalan yang menyangkut isu kekuasaan, budaya dan campur tangan pemerintah dalam urusan adat. Pertama, pemahaman yang berbeda antar para Ninik Mamak soal penafsiran adat-istiadat serta dengan aparatur nagari tentang makna dan hakikat kembali bernagari. Para Ninik Mamak menganggap kembali ke nagari berarti menempatkan kembali unsur tali tigo sapilin, tungku tigo sajarangan sebagai unsur masyarakat yang paling penting dalam pengambilan keputusan sama dengan kondisi nagari sebelum era kolonial. Kedua, pemerintah sebagai pemangku kebijakan tidak memahami adat-istiadat yang berkembang di nagari, namun ikut campur tangan terlalu dalam mengurusi kewenangan kelembagaan adat. Dampaknya banyak lembaga adat yang hilang dan tidak diakui serta muncul kelembagaan adat baru yang di modifikasi namun tidak memiliki orientasi filosofis sesuai adat salingka nagari. Ketiga, Ninik Mamak tidak terlalu memahami tata administrasi formal seperti mekanisme pembuatan keputusan adat yang harus disahkan ke pemerintah kabupaten agar menjadi peraturan yang mengikat. Kondisi ini membuat kelembagaan formal dengan gampang dapat memainkan pola dominasinya dan turut ikut campur dalam urusan adat. Keempat, Ninik Mamak mengalami ketergantungan dengan Wali Nagari akibat anggaran yang diatur dan diberikan wali nagari kepada KAN pada program pembinaan masyarakat di dalam nagari.

Dalam agenda baliak ka nagari, terdapat simpang siur pemahaman tentang bagaimana sebaiknya pemerintahan nagari dilaksanakan. Banyak wacana perorangan atau kelompok yang telah diusulkan untuk memodifikasi pemerintahan nagari. Wacana-wacana tersebut secara umum mengarahkan kepada konsep penyederhanaan pemerintahan nagari agar selaras dengan cita-cita daerah dan nasional. Akibat orientasi wacana seperti itu, banyak terjadi perubahan-perubahan dalam tubuh nagari yang menimbulkan kebingungan di

\section{Tabel 1. Perbandingan situasi sosial dan politik Nagari Pariangan}

\begin{tabular}{|c|c|}
\hline Pariangan Sebelum Kolonial Belanda & Pariangan Masa Reformasi \\
\hline $\begin{array}{l}\text { 1. Pemimpin tertinggi adalah penghulu dan para } \\
\text { Ninik Mamak yang terwadahi di dalam KAN }\end{array}$ & $\begin{array}{l}\text { 1. Dualisme kepemimpinan antara Wali Nagari sebagai } \\
\text { pelaksana daerah yang dianggap pemimpin formal } \\
\text { dan KAN sebagai pelaksana adat yang ditentukan } \\
\text { oleh pemerintah dan dianggap pemimpin informal }\end{array}$ \\
\hline $\begin{array}{l}\text { 2. Nagari memutuskan kebijakan melalui } \\
\text { musyawarah mufakat unsur tali tigo sapilin, } \\
\text { tungku tigo sajarangan }\end{array}$ & $\begin{array}{l}\text { 2. Masih kuatnya intervensi pemerintah provinsi dan } \\
\text { kabupaten, terlihat dari banyak kelembagaan adat } \\
\text { yang tidak diakui pemerintah dan akhirnya hilang. } \\
\text { Selain itu, pentingnya petunjuk teknis pelaksanaan } \\
\text { pemerintahan Nagari yang dibuat oleh pemerintah } \\
\text { sehingga tanpa itu, aparatur Nagari kebingungan } \\
\text { dalam menjalankan tugas }\end{array}$ \\
\hline $\begin{array}{l}\text { 3. Hukum adat berada diatas segalanya melebihi } \\
\text { hukum Negara }\end{array}$ & $\begin{array}{l}\text { 3. Ketergantungan anggaran dan pembatasan } \\
\text { wewenang adat menggunakan landasan hukum } \\
\text { formal. }\end{array}$ \\
\hline $\begin{array}{l}\text { 4. Nagari Pariangan membawahi ampek koto diateh, } \\
\text { ampek koto dibawah }\end{array}$ & $\begin{array}{l}\text { 4. Dengan hadirnya kecamatan, Nagari Pariangan } \\
\text { hanya membawahi } 4 \text { jorong dibawahnya dengan } \\
\text { wali-wali jorong yang bertanggung jawab kepada } \\
\text { Wali Nagari }\end{array}$ \\
\hline
\end{tabular}


tengah masyarakat bahkan kesalahpahaman tentang kembali bernagari timbul di tubuh KAN. Mayoritas, dari 22 Ninik Mamak yang ada di Nagari Pariangan tidak memahami soal pengaturan-pengaturan kewenangan Ninik Mamak beserta fungsi administratif sesuai ketentuan kebijakan baliak ka nagari.

Masyarakat menganggap kondisi nagari sekarang sama dengan kondisi nagari sebelum kolonial dimana seluruh keputusan tertinggi dan roda pemerintahan masih di dominasi oleh kelembagaan adat. Sebagaimana dikatakan oleh lembaga unsur Cadiak Pandai pariangan bahwa kuatnya pengaturan dari pemerintah dan berubah-ubah terhadap adat menimbulkan kebingungan ditengah masyarakat khususnya Ninik Mamak, kondisi di Nagari Pariangan pemerintah tidak pernah melibatkan para Ninik Mamak dalam merumuskan kebijakan mengenai adat sehingga dalam agenda nya Ninik Mamak hanya di mobilisasi oleh pemerintah untuk menjalankan adat agar selaras dengan pemerintah tanpa memahami bagaimana kewenangan-kewenangan yang seharus nya didapatkan oleh Ninik Mamak.

\section{Penetrasi Negara dalam Nagari Pariangan di Era Otonomi Daerah}

Penetrasi yang dimaksud dalam studi ini adalah kebijakan atau tindakan yang diambil oleh negara ataupun daerah dalam merumuskan dan menegakkan aturan permainan dalam kehidupan sosial, politik dan ekonomi masyarakat. Karena negara dan daerah sebagai institusi politik sesungguhnya memainkan dua fungsi penting. Pertama, mengatur bukan mengontrol kelompok masyarakat. Kedua, memonopoli dan membatasi kewenangan yang sudah diberikan melalui supra-struktur negara dan daerah yang hadir di tengah kelompok masyarakat. Penulis mencoba mengidentifikasi bentuk-bentuk penetrasi melalui kebijakan, kelembagaan formal, aktoraktor informal dan proses politik yang dihadirkan daerah untuk menciptakan aturan permainan di dalam nagari seperti yang digambarkan pada tabel dibawah ini.

Meskipun telah memasuki era reformasi dan pemerintahan adat nagari di Sumatera Barat secara empiris telah dihidupkan kembali, negara tidak benar-benar memberikan kewenangan adat untuk menjalankan seluruh pranatapranata hukum adat beserta kelembagaannya di dalam nagari, khususnya Pariangan. Penetrasi politik negara erat kaitannya dengan kehadiran lembaga-lembaga negara di dalam nagari yang mengatur masyarakat nagari secara formal

Tabel 2. Penetrasi dalam Nagari Pariangan Pasca Reformasi

\section{Model Penetrasi \\ Bentuk Penetrasi \\ Implikasi}

\begin{tabular}{|c|c|c|}
\hline Kebijakan & $\begin{array}{l}\text { - Perda Provinsi No } 9 \text { Tahun 2000, } \\
\text { Perda No } 2 \text { Tahun 2007, Perda } \\
\text { Kabupaten Tanah Datar No } 4 \text { Tahun } \\
\text { 2008 dan Raperda tahun } 2017 \text { sebagai } \\
\text { respon dari UU No } 6 \text { Tahun } 2014 \text {. } \\
\text { Seluruh peraturan tersebut mengatur } \\
\text { kewenangan-kewenangan lembaga } \\
\text { adat dalam upaya penyempurnaan } \\
\text { pemerintahan nagari. } \\
\text { - Agendamenyesuaikan kelembagaan } \\
\text { adat dan kelembagaan pemerintah } \\
\text { - Penerapan petunjuk teknis pemerin- } \\
\text { tahan nagari } \\
\text { - Kebijakan pembangunan pariwisata } \\
\text { nagari pariangan }\end{array}$ & $\begin{array}{l}\text { - Dengan berubah-ubahnya ketentuan } \\
\text { kewenangan lembaga adat yang di } \\
\text { tentukan pemerintah tanpa melibatkan } \\
\text { tokoh adat menyebabkan kebingungan } \\
\text { terjadi pada lembaga adat dalam } \\
\text { menjalankan pemerintahan adat di } \\
\text { dalam nagari } \\
\text { Banyak lembaga adat yang hilang } \\
\text { dan tidak di akui pemerintah karena } \\
\text { tumpang tindih fungsi dengan } \\
\text { kelembagaan pemerintah seperti malin, } \\
\text { pandito, dubalang dan Parikpaga nagari } \\
\text { Penerpan petunjuk teknis membuat } \\
\text { aparatur nagari ketergantungan } \\
\text { dengan pemerintah karena tanpa hal } \\
\text { itu, aparatur nagari tidak memahami } \\
\text { ketentuan dan kewenangan lembaga- } \\
\text { lembaga di dalam nagari } \\
\text { Dengan kebijakan pembangunan } \\
\text { pariwisata kebudayaan di pariangan, } \\
\text { sering kali pemerintah turut campur } \\
\text { dalam mengatur urusan adat. }\end{array}$ \\
\hline
\end{tabular}




\section{Kelembagaan Formal}

\begin{abstract}
Aktor-Aktor Informal
\end{abstract}

Proses Politik
- Masih hadir Lembaga Kerapatan Adat Alam Minangkabau (LKAAM) sebagai lembaga adat bentukan pemerintah yang bertugas menselaraskan KAN di setiap nagari dengan kepentingan pemerintah.

- Tahun 2004, pemerintah membentuk lembaga Tata Pemerintahan Nagari (Tapemnag) yang bertugas mengurusi bentukbentuk pemerintahan nagari dalam mewujudkan agenda pemberlakuan administratif seperti pendaftaran pusako, pengesahan peraturan nagari dan lain sebagainya.

- Untuk mewujudkan agenda pembangunan pariwisata di pariangan, pemerintah merangkul aktor-aktor intelektual adat untuk membentuk komunitas pariangan.

- Pemerintah turut berperan dalam agenda adat batagak gala di dalam musyawarah tali tigo sapilin, tungku tigo sajarangan, atau penentuan gelar datuak sebagai gelar kehormatan adat Minangkabau
- Jika ada kebijakan KAN tentang adat yang bertentangan dengan pemerintah. Maka pemerintah akan menolak kebijakan tersebut melalui LKAAM.

- Dengan fungsi Tapemnagyang mengesahkan dan menerbitkan peraturan nagari setelah melalui proses koreksi oleh tapemnag. Sering kali peraturan nagari khususnya mengenai adat tersebut digagalkan jika bertentangan dengan agenda pemerintah

Peranan aktor intelektual adat tersebut dalam mengembangkan pariwisata kebudayaan di pariangan, cenderung mengambil alih fungsi Ninik Mamak dan tidak pernah melibatkan Ninik Mamak dalam pengambilan keputusan.

- Agendaadatiniseringsekalimendapatkan intervensi dari banyak pihak. Akibatnya berpotensi menimbulkan konflik dalam penentuan gelar di internal nagari. dan informal era desentralisasi. Dalam satu dasawarsa, pemerintah melakukan unifikasi terhadap pranata adat-istiadat ke dalam ketentuan-ketentuan formal untuk mengatur batas-batas kewenangan dan keberlangsungan kelembagaan adat yang ada di nagari. Secara otomatis hukum formal, aturan, dan struktur administratif yang dibentuk berupaya menyeragamkan adat secara regional dan selaras dengan kepentingan daerah dan Negara.

\section{Kegagalan Otonomi Daerah Dalam Kebijakan Penyempurnaan Nagari \\ Historical institusionalism berusaha} mengidentifikasi transformasi kelembagaan yang dipengaruhi oleh perubahan undangundang secara formal dan koalisi elit lokal berkepentingan secara informal sehingga menghasilkan status quo dalamkeberlangsungan nagari. Perubahan nagari yang terjadi menghasilkan sebuah rangkaian kebijakan dan keputusan lainnya yang saling berkaitan, bertahan dan berulang pada setiap hasil politik yang dikeluarkan. Deskripsi munculnya nagari di era reformasi memberikan gambaran bahwa proses transisi pola kelembagaan dan distribusi kewenangan terhadap lembaga adat pada setiap rangkaian kebijakan yang dikeluarkan oleh pemerintah cenderung dilematis dan masih banyak kelemahan.

Tidak ada distribusi otonomi yang benar-benar diberikan oleh Negara terhadap kembalinya nagari sebagai pemerintahan tradisional. Selalu ada pembatasan kewenangan bahkan campur tangan pemerintah terhadap kewenangan adat yang cenderung membuat ketergantungan lembaga adat kepada pemerintah semakin tinggi seperti pada era Orde Baru, meskipun daerah melalui ketentuannya telah mengakui keberadaan kelembagaan adat tertentu dalam tatanan pemerintahan lokal. Penulis mencoba membandingkan perubahan ketentuan desa sesuai dengan Undang-Undang Nomor 5 Tahun 1979 pada era Orde Baru dan Undang-Undang Nomor 22 Tahun 1999 di era reformasi yang dianggap sebagai pola pengaturan desa yang berulang dan bertahan.

Logika utama Undang-Undang Nomor 5 Tahun 1979 bertujuan untuk mewujudkan dua pilar agenda pembangunan ekonomi Orde Baru dan stabilitas nasional yang dapat dicapai jika pemerintah pusat menguasai sepenuhnya pedesaan. Design kebijakan ini cenderung menggunakan masyarakat lokal 
sebagai kendaraan untuk mencapai tujuan tersebut. Sehingga untuk mewujudkan agenda pembangunan Negara, sistem yang berkembang di dalam masyarakat lokal harus disederhanakan dan selaras dengan kepentingan Negara. Masyarakatterstandarisasimelaluipenyeragaman bentuk pemerintahan desa dengan mewajibkan seluruh bentuk pemerintahan terendah harus berbentuk desa serta memiliki struktur kepala desa dan majelis permusyawaratan desa. Undang-Undang Nomor 5 Tahun 1979 secara jelas mendefinisikan sifat desa sebagai tingkat terendah dibawah kecamatan, sementara sisi lain kebijakan undang-undang tersebut menyatakan bahwa desa memiliki hak untuk mengelola urusannya sendiri.

Mencermati agenda pemerintah pada setiap kebijakan dalam membentuk, mengatur dan menyeragamkan bentuk pemerintahan terendah dari periode orde baru sampai era pasca reformasi sebagaimana dijelaskan di atas. Memberikan gambaran bahwa pemerintah berupaya menjaga stabilitas nasional dan menjalankan agenda pembangunan serta menghadirkan fitur-fitur kelembagaan modern pada setiap desa atau bentuk pemerintahan tradisional lainnya. Tidak banyak perubahan yang terjadi, kekuasaan tertinggi dalam struktur pemerintahan tradisional tetap pada pemerintah dan kepala desa. Peraturan desa dan anggaran desa masih ditetapkan oleh BPD dan kepala desa serta disahkan oleh supra-struktur tanpa melibatkan unsur adat bagi daerah yang menerapkan pemerintahan tradisional. Daerah dalam memainkan dominasinya menciptakan perluasan birokrasi modern di nagari, sehingga artinya tujuan mengembangkan pemerintahan tradisional tidak sepenuhnya memberikan kewenangan unsur pemerintahan tradisional untuk mengatur dirinya sendiri melainkan meningkatkan peran mereka dalam mendukung proses pembangunan ekonomi dan stabilitas nasional.

Berdasarkan analisis historical institutionalism, penulis menganggap bahwa rangkaian kebijakan otonomi daerah dan agenda menghidupkan bentuk pemerintahan tradisional merupakan pengaruh dari kebijakan desa saat orde baru dengan tetap dipertahankannya fitur kelembagaan modern, serta campur tangan pemerintah yang sama seperti era orde baru dalammengatur desa sebagai alat pembangunan, meskipun otonomi kelembagaan telah didis- tribusikan sebagaimana di atur dalam setiap perubahan rangkaian undang-undang. Pola tersebut berulang dan bertahan pada kebijakan kembali ke nagari, ketentuan hukum formal melahirkan perubahan orientasi struktural dan kultural kelembagaan adat di nagari ke arah sistem yang lebih modern sebagaimana dijelaskan pada pembahasan sebelumnya.

\section{Analisis Historical Institutionalism Pada Transformasi Nagari Pariangan di era otonomi daerah}

Dalam menjelaskan dinamika transformasi nagari, penulis melihat variabel perubahan di nagari pariangan menggunakan analisa historical institusionalism. Pendekatan ini mengidentifikasi bounded rationality dalam aturan, pola informal dan struktur administratif yang mempengaruhi kelembagaan dan kebijakan yang dihasilkan dalam proses temporal yang tetap. Path dependence atau jalur ketergantungan sebagai unit analisis historical institusionalism menjadi alat untuk membedah nagari yang telah mengalami penataan kelembagaan dalam agenda kembali bernagari sejak periode tahun 2000 melalui design pengaturan dan pola-pola pendisiplinan yang dihasilkan oleh pemerintah Provinsi Sumatra Barat sehingga mempengaruhi rangkaian kebijakan kembali ber-nagari setiap periode.

\section{Keterlibatan Kekuatan-Kekuatan Politik dalam Penyempurnaan Nagari Pariangan}

Tulisan ini mengidentifikasi bahwa pemerintah menghadirkan aktor-aktor intelektual nagari pariangan untuk turut ikut campur tangan dalam agenda penyempurnaan nagari dan cenderung merebut kewenangan KAN dan membatasi dalam membuat keputusankeputusan politik soal pemerintahan nagari karena dianggap tidak dapat menjalankan roda pemerintahan nagari sebagaimana digambarkan pada gambar 1.

Dominasi dalamketentuan penyempurnaan nagari pada dasarnya merupakan keinginan pemerintah untuk menciptakan birokrasi modern, efisien dan efektif dalam rangka memelihara stabilitaspolitiksebagaipersyaratanpembangunan ekonomi di era otonomi daerah. Berbagai usaha dilakukan dalam rangka pembenahan birokrasi berupa penataan organisasi, peningkatan keterampilan dan kecakapan teknis aparatur nagari. Agenda menselaraskan seluruh bentuk 
Gambar 1. Penetrasi lembaga formal dan Informal

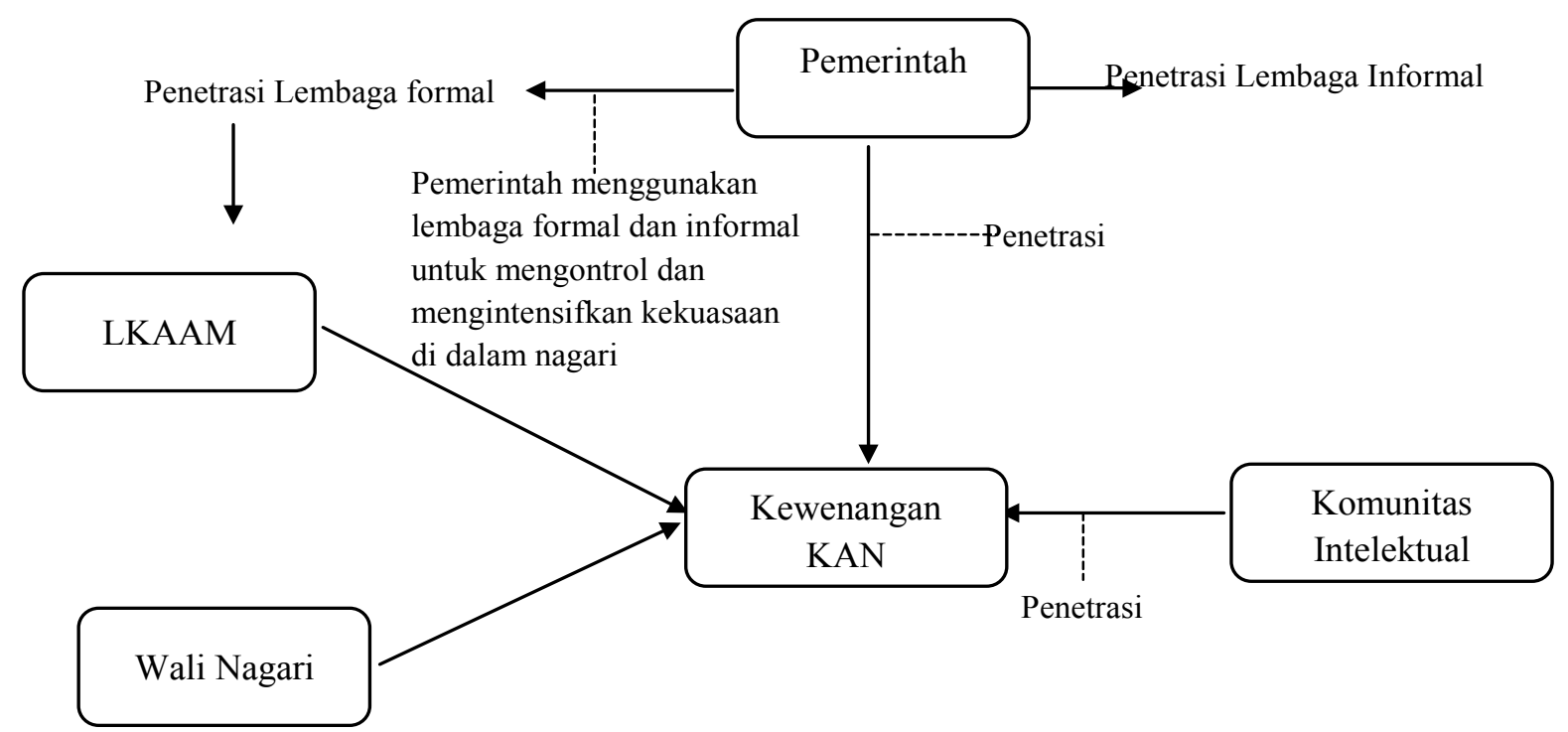

pemerintahan nagari merupakan salah satu cara untuk mewujudkan keinginan pemerintah tersebut. Akibat partisipasi politik masyarakat Pariangan sangat rendah, membuat pemerintah menganggap perubahan tidak mungkin berasal dari tekanan domestik. Hal itu yang membuat segala kewenangan dan kelembagaan yang ada di dalam nagari di dominasi oleh birokrasi. Sementara lembaga adat berada dalam keadaan lemah dan tidak mampu mengimbangi atau mengontrol kekuasaan birokrasi.

Alasan lain atas melemahnya adat yang terdiferensiasi secara lokal disebabkan hadirnya Lembaga Kerapatan Adat Alam Minangkabau (LKAAM) sebagai sebuah lembaga adat resmi tingkat provinsi dan kabupaten, LKAAM dibentuk oleh sekelompok penghulu terdidik perkotaan dan mayoritas di antara mereka adalah pegawai negeri sipil, yang berkepentingan melestarikan dan menyebarluaskan informasi tentang adat Minangkabau. Oleh karena LKAAM diorganisasikan di bawah naungan pemerintah, lembaga ini hanya sekedar menjadi perpanjangan tangan dalam upaya mengintensifkan kekuasaan di dalam nagari. LKAAM merupakan warisan orde Baru yang sampai hari ini keberadaannya masih tetap dipertahankan untuk mengontrol dan menselaraskan KAN di setiap nagari. Tidak jarang jika ada ketentuanketentuan adat yang tidak disepakati oleh pemerintah, maka pemerintah akan menolak ketentuan adat tersebut melalui LKAAM.

Kondisi ini membuat dalam urusan adat LKAAM menjadi alat pemerintah untuk mengendalikan KAN agar selalu berada dalam kontrol pemerintah. Sebagai contoh pemerintah akan campur tangan ke lembaga adat melalui LKAAM jika terjadi perselisihan perebutan gelar Datuk sebagai gelar kehormatan di dalam adat. Sengketa ini merupakan salah satu kasus yang sering mendapatkan inter-vensi daribanyak pihak karena dalam era kontemporer, gelar adat menjadi syarat penting untuk mendapatkan posisi kekuasaan dan dapat digunakan sebagai alat mobilisasi agar lebih dekat dengan akses publik dalam mencapai tujuan ekonomi maupun politik. Patronase pemerintah didalam LKAAM tidak dapat dihindari lagi, karena pemerintah memberikan alokasi anggaran sebagai ganti untuk mendapatkan loyalitas dari LKAAM agar menjalankan seluruh kepentingan pemerintah dalam urusan adat. Kondisi ini membatasi kewenangan lembaga adat dalam menjalankan pemerintahan di nagari. Tidak jarang penolakan KAN terhadap kehadiran LKAAM yang dianggap terlalu mendominasi dalam seluruh agenda adat di nagari. KAN menganggap bahwa LKAAM bukan lembaga adat, melainkan lembaga bentukan pemerintah yang berupaya menyelaraskan adat dengan kepentingan pemerintah.

Kekuatan politik yang mencampuri urusan adat dalam nagari tidak berhenti pada LKAAM. Komunitas intelektual yang ada di nagari pariangan juga turut ambil bagian dalam melakukan pengaturan-pengaturan adat terhadap nagari yang seharusnya menjadi kewenangan ninik mamak. Dengan status yang disematkan oleh majalah internasional American Budget Travelling kepada nagari pariangan sebagai salah satu desa terindah di dunia, membuat interaksi pemerintah dengan 
komunitas-komunitas intelektual di dalam nagari pariangan semakin intens terjadi. Upaya pemerintah merangkul komunitas ini untuk mewujudkan nagari pariangan sebagai nagari pariwisata guna merespon status yang disematkan oleh pariangan sebagai desa terindah. Sisi lain hal ini sesuai dengan agenda pembangunan daerah yang berusaha mendorong peningkatan pariwisata di Kabupaten Tanah Datar.

Pemerintah mendorong dan memberdayakan elemen masyarakat untuk membentuk komunitas yang di dominasi oleh aktor intelektual adat untuk mempertahankan peninggalan sejarah dan simbol-simbol adat lainnya di dalam nagari pariangan. Di bawah koordinasi pemerintah komunitas ini juga memiliki tujuan untuk mengembangkan potensi wisata pariangan agar menarik para wisatawan datang. Upaya membangkitkan adat-istiadat oleh komunitas tersebut terus dilakukan demi memperlihatkan kepada wisatawan bahwa pariangan masih mempertahankan otentisitas adat Minangkabau. Agenda pembangunan pariwisata kebudayaan ini sama sekali tidak melibatkan unsur KAN dalam pengambilan keputusan, murni di dominasi oleh aktor intelektual adat dan unsur pemerintah yang berlomba-lomba mengembangkan serta mengkomoditaskan kebudayaan di pariangan. Padahal dalam pengembangan dan pembangunan nagari merupakan kewenangan KAN untuk turut memutuskan dan mengesahkan segala kebijakan yang bersentuhan dengan adat-istiadat.

Pasca ditetapkannya pariangan sebagai nagari pariwisata, menyebabkan banyak pengembangan yang dilakukan oleh pemerintah dalam upaya memperluas akses pariwisata di dalam pariangan. Kondisi itu berdampak pada tanah pusako masyarakat pariangan banyak disewakan kepada pemerintah untuk dibangun akses pariwisata seperti parkiran dan penginapan-penginapan untuk para wisatawan yang datang ke pariangan, tidak jarang masyarakat menolak untuk menyewakan tanahnya kepada pemerintah karena mayoritas masyarakat bergantung kepada penghasilan pertanian di tanah pusako mereka.

Pemerintah melalui Wali Nagari cenderung memaksa masyarakat pariangan untuk menyewakan tanah pusako tersebut. Sebenarnya dalam ketentuan adat yang berlaku tanah pusako tidak boleh disewakan kecuali dalam situasi yang mendesak. Okupasi tetap dilakukan oleh pemerintah tanpa memperhatikan hukum adat yang berkembang demi mewujudkan pengembangan pariwisata. Kondisi ini memperlihatkan, masyarakat dimobilisasi oleh pemerintah dan aktor-aktor intelektual adat agar dapat mengkomoditaskan adat-istiadat. Seharusnya dalam agenda ini pemerintah mendistribusikan kewenangan pengelolaan pariwisata kepada KAN, di sisi lain agar kebijakan pengembangan pariwisata di dalam pariangan tidak bertentangan dengan ketentuan adat serta menjaga otentisitas adat meskipun interaksi yang semakin terbuka akibat banyaknya wisatawan yang datang ke pariangan.

Kepentingan perebutan sumber daya antara negara dan nagari masih terus berlangsung, berbagai macam perubahan untuk membatasi kekuasaan nagari dihasilkan oleh daerah baik melalui norma hukum maupun kegiatan informal. Sebagaimana temuan penulis di nagari pariangan dalam upaya aktoraktor intelektual membangkitkan adat untuk kemudian dapat dikomoditaskan melalui konsep nagari pariwisata, segala hal dilakukan untuk mewujudkan tujuan teresbut. Mereka membentuk jaringan kerjasama untuk bersamasama membatasi kewenangan dan keputusan KAN serta menyokong komunitas intelektual untuk merebut kewenangan KAN khususnya dalam pembangunan nagari pariwisata di pariangan.

\section{SIMPULAN}

Pengakuan kembali Nagari sebagai pemerintahan terendah ternyata menempatkan nagari pada kondisi yang dilematis, nagari harus menerima intervensi pemerintah yang menempatkannya sebagai bagian dari birokrasi negara. Keadaan ini sesungguhnya membuat nagari secara substansial berbentuk desa, karena yang menjadi salah satu ciri utama dari pemerintahan nagari berdasarkan format lama adalah dengan adanya kewenangan kepemimpinan kolektif tali tigo sapilin, tungku tigo sajarangan.

\section{UCAPAN TERIMA KASIH}

Ucapan terima kasih diberikan kepada masyarakat Adat Nagari Pariangan Sumatera Barat yang sangat partisipatif dan mendukung dalam proses penyelesaian penelitian ini. 


\section{DAFTAR PUSTAKA}

Astuti, N.B., Kolopaking, L.M., \& Pandjaitan, N. K. (2009).Dilema dalam Transformasi Desa ke Nagari: Studi Kasus di Kenagarian IV Koto Palembayan, Provinsi Sumatera Barat. Jurnal Transdisiplin Sosiologi, Komunikasi, dan Ekologi Manusia , 3 (2), 3.

Biezeveld, R. (2010). Ragam Peran Adat di Sumatra Barat. In J. S. Davidson, D. Henley, \& S. Moniaga, Adat Dalam Politik Indonesia (pp. 221-244). Jakarta: Yayasan Obor Indonesia

de Jong, P.d. (1980). Minangkabau and Negeri Sembilan: Socio-Political Structure in Indonesia. Den Hag: Springer Netherlands.

Davidson, J.S. (2010). Adat dalam Politik Indonesia. Jakarta: Yayasan Pustaka Obor Indonesia.

Davis, Brian, L. (2004). State Power and Community in Early Modern Russia. New York: Palgrave Macmillan.

Hadler, J. (2014). Sengketa Tiada Putus: Matriarkat, Reformisme Islam, dan Kolonialisme di Minangkabau. Jakarta: Freedom Institute.

Hasanuddin. (2013). Adat dan Syarak. Padang: Pusat Studi Minangkabau Universitas Andalas

Isra, S. (2014). Political and Legal Transformations of an Indonesian Polity: The Nagari from Colonization to Decentralization. Bulletin of Indonesian Economic Studies , 3 (50), 493-495.

Kahn, J.S. (1980). Minangkabau Social Formation: Indonesian Peasants and the World Economy. London: Cambridge University Press.

Kuyper, J. (2014) Transformative Pathways To World Government: A Historical Institutionalist Critique, Cambridge Review of International Affairs, 28(4).

Migdal, J.S. (2004). State in Society: Studiying How States and Societies Transform and Constitute One Another. Cambridge: Cambridge University Press. London: Pluto Press.
Muhammad, J. (2015). Dilema Pemangku Adat Minangkabau. Bukittinggi: Cinta Buku Agency.

Nutijen, M. (2003). Power, Community and The State. The Political Anthropology of Organisation in Mexico.

Patji, Rachman, A. (2004). Negara dan Masyarakat Dalam Konflik Aceh. Studi Tentang Peran Pemerintah dan Masyarakat Dalam Penyelesaian Konflik Aceh. Jakarta: Lembaga Ilmu Pengetahuan Indonesia (LIPI).

Samad, R.S. (2010). Negara dan Masyarakat: Studi Penetrasi Negata di Riau Kepulauan Masa Orde Baru. Yogyakarta: Pustaka Pelajar.

Steinmo, S. (2014). Historical Institu-tionalism and Experimental Methods, Paper presented at the American Political Science Association meeting, August 29, 2014

Thamrin,A. (2015). Prospek Nagari Adat Dalam Rezim UU Desa Di Sumatera Barat Terhadap Pembangunan Masyarakat Sosial-Budaya ASEAN. Jurnal Ilmu Politik FISIP Universitas Andalas , 4

Hansen, T. \& Stepputat, F. (2001). State of Imagination. London : Duke University Press.

Tsai, Kellee, S. (2014). Informal Institution and Historical Institutionalism. Paper presented at the 2014 Annual Meeting of the American Political Science Association (APSA), August 28-31, 2014, Washington D.C

Tegnan, H. (2015). Legal pluralism and land administration in West Sumatra: the implementation of the regulations of both local and nagari governments on communal land tenure. The Journal of Legal Pluralism and Unofficial Law , 2 (47), 312-323.

von Benda-Beckmann, K., \& von BendaBeckmann, F. (1978). Residence in Minangkabau Nagari. Indonesia Circle. School of Oriental and African Studies , 6 (15), 6-17.

von Benda-Beckmann, F. (1979). Property in Social Continuity: Continuity and 
Change in The Maintance Of Property Relationship Through Time In Minangkabau, West Sumatra. London: The Hague: Martinus Nijhoff

von Benda-Beckmann, F., \& von BendaBeckmann, K. (2006). Changing One is Changing All: Dynamics in the Adat-Islam-State Triangle. (Kahn, 1980)The Journal of Legal Pluralism and Unofficial Law , 38 (5354), 239270.

von Benda-Beckmann, F., \& von BendaBeckmann, K. (2012). Identity in dispute: law, religion, and identity in Minangkabau. Asian Ethnicity, 13 (4), 341-358.

von Benda-Beckmann, K., \& von BendaBeckmann, F. (2013). Political and Legal Transformations of an Indonesian Polity: The Nagari from Colonization to Decentralization. London: Cambridge University Press
Vel, J., \& Bedner, A. (2015). Decentralisation and Village Governance in Indonesia: The Return to the Nagari and the 2014 Village Law. The Journal of Legal Pluralism and Unofficial Law , 47 (3), 493-507.

Yasril, Y. (2007). Model Pemerintahan Nagari Yang Partisipatif dalam Masyarakat Minangkabau. DEMOKRASI, 214.

Yusril, Y. (2000). Pemerintahan Nagari di Era Orde Baru: Persepsi Aparatur Pemerintah dan Masyarakat Terhadap Pemerintahan Nagari dan Otoritas Tradisional Minangkabau Dalam Kaitannya Dengan Prospek Otonomi Daerah di Sumatera Barat. Program Pasca Sarjana Universitas Brawijaya Malang, 2 .

Zed, M., Utama, E., \& Chaniago, H. (1998). Sumatera Barat di Panggung Sejarah 1945-1995. Jakarta: Pustaka Sinar Harapan.

Zuhro, R.S. (2009). Demokrasi Lokal: Perubahan dan Kesinambungan (NilaiNilai Budaya Politik Lokal di Jawa Timur, Sumatera Barat, Sulawesi Selatan dan Bali). Yogyakarta: Ombak. 